QIJIS: Qudus International Journal of Islamic Studies

Volume 6, Issue 2, Agustus 2018

\title{
BANK SELECTION CRITERIA AND SERVQUAL SURVEY AMONG MUSLIMS IN MAURITIUS
}

\author{
Muhamad Abduh \\ School of Business and Economics, Universiti Brunei Darussalam \\ muhamad.abduh@ubd.edu.bn \\ Shaheen Bibi Ramjaun \\ Afr Asia Bank Limited Port Louis, Mauritius \\ shaheen.ramjaun@gmail.com \\ Muhamad Mustaqim \\ Institut Agama Islam Negeri Kudus \\ muhamadmustaqim10@gmail.com
}

\begin{abstract}
As a Muslim minority country located far off the east coast of South Africa, Mauritius has successfully introduced Islamic finance since 1998. However, the development is not as expected since two Islamic banking windows were closed down and the only Islamic commercial bank in the country has been struggling hard in order to generate favorable expected profits. The aim of this study are to investigate the bank selection criteria among Muslims in Mauritius and to evaluate the customer satisfaction upon the Islamic banking service quality in the country. The findings show that privacy, easy access, service quality, facilities, transparency and bank reputation are the factors influence Muslim Mauritian to patronize bank and interesting lyreligion and religiosity are out
\end{abstract}


of it. The importance - performance analysis is used to provide an interesting visual analysis on the service quality items examined. The findings suggest that Islamic banks must improve their Tangible and Reliability aspects in order to satisfy the customers and eventually become more profitable.

Keywords: Mauritius, Islamic bank, bank selection criteria, service quality, importance-performance analysis.

\section{A. Introduction}

The finance world today incorporates two types of financial system, the conventional system and the Islamic financial system. The former has shown its limits in recent years with financial crises originating in one country and spreading like wild fire across borders throughout the world. Furthermore, the credit crunch and Murdoch scandal have demonstrated the hollow foundations of this interest-based financial system. On the other hand, the latter has shown its strength with steady growth over the years despite the global financial crises which happened cyclically. Nowadays, Muslim majority countries such as Malaysia, Indonesia, the Middle East countries and Muslim minority ones such as United Kingdom, United States, Singapore, and Hong-Kong have the Islamic finance modes of financing operated in parallel with the existing conventional finance in the country.

Mauritius, situated some $2000 \mathrm{~km}$ off the east coast of South Africa is no exclusion. Islam has the second largest adherents in the country which amounts to around $20 \%$ of total population after Hinduism and followed by Christianity. Islamic finance in Mauritius has been informally present through a cooperative society named Al-Barakah since 1998 which can therefore be characterized as being the pioneer for Islamic financial institution in the country. The society has been able to thrive till now on the account of the friendly legal framework for cooperative societies in 
the Island. Nevertheless, till now it has been the sole cooperative society using Islamic finance contracts with no other competitor.

Meanwhile, the first Islamic commercial banking in Mauritius, namely Century Bank, was introduced in 2011 when the Central Bank of Mauritius amended its Banking Act 2004 into the Finance Act 2007 so as to provide proper legislative frameworks for Islamic banking. Further to this, in 2009 the Finance Act was again amended into the Finance Act 2009 where the Government made certain provisions which include the facilitation for issuing sukuk in the country. Other legal changes comprise of changes in Registration Duty Act and Stamp Duty Act where double duties payable under Islamic modes of financing were removed. The Central Bank has also issued its own set of guidelines to be followed by Islamic banks or windows.

However, despite the country's financial sector growing at a decent rate with banking assets contributing $10.7 \%$ of their GDP, there has been a very little progress so far with Islamic financial industry (Lallmahamood, 2013). Until now, two Islamic banking windows were closed down and the only Islamic commercial bank in the country has been struggling hard in order to generate favorable expected profits. Therefore, through a quantitative survey, this study is generally aimed at investigating the behavior of Muslim population in Mauritius towards bank selection criteria and how they perceive the performance of Islamic finance industry in Mauritius.

This study is divided into five parts. The first part introduces Islamic finance in Mauritius and the background of this study. The literature on the conventional and Islamic banking sector in Mauritius as well as previous related studies done in other countries are discussed in the second part. The third part explains about the data and methods chosen in this study. Part four discusses and explains the findings together with the research implications. Finally, the conclusion derived from the study and suggestions for further research are provided in part five. 


\section{B. Discussion}

\section{Islamic Finance in Mauritius}

Gunputh (2012) argues that Mauritius does have the proper environment and framework to become a successful Islamic finance hub in Africa. The study shows that Mauritius being a highly ranked country by the World Bank in ease of doing business and owning a sound and very well diversified economic system has all that it needs to develop a lucrative Islamic financial industry. The fact that Mauritius is a Non-Muslim country should not cause any problem in developing the industry. Indeed, other Non-Muslim countries such as UK has a thriving Islamic finance industry and Hong Kong is expected to have a rapid growth rate in Islamic finance in the next five years, even surpassing countries like Tunisia and Egypt according to a Thomson Reuters report in February 2014.

Similarly, while conducting a review on Islamic finance in Africa, Faye et.al (2013) mentions that having a very stable and advanced financial sector, Mauritius has great prospects in developing its Islamic finance industry. They also evidence that in spite of being a latecomer in the sukuk market, Mauritius was ranked the second in Africa in raising funds of USD 560 million through sukuk issuance. However, their study shows that even though the country has a robust financial system, other less developed African economies, especially in Northern part, are more advanced with regards to Islamic finance. They conclude that this might be due to strong cultural and religious ties between North African countries and the Gulf countries. On the other hand, Mauritius being in the Southern area, might find it difficult to attract potential investors from the rich Arab lands since it does not share any strong relationship with them.

Without a doubt, Mauritius fulfils all the needs in order to expand the industry. However, it is also a questionable fact that in spite of the Government trying to boost up the Islamic financial system, little development has been seen till now. The only fully 
fledged Islamic bank has been struggling to generate profit. According to their 2013 financial statements, the loss for the year of 2012 amounted to Mauritian Rupees (MUR) 36.5 million which approximately equals to USD 1 million (Century Banking Corporation Ltd, 2013). Furthermore, HSBC Amanah closed down its window in the country in early 2012 (Jenkins and Hall, 2012).

As of now, there is no Takaful company in Mauritius. One Takaful scheme was provided by BAI (British American Insurance Co Ltd) since 2008 but the company closed down in early 2015 due to certain financial issues. On the other hand, Mauritius has not yet ventured into the world of shariah compliant securities. The government was hoping to issue sovereign sukuk since 2009; however, in spite of government's efforts, the country failed to do so due to unknown reasons. The previous governor of the central bank in fact described Mauritius' progress in Islamic finance as being 'foot-dragging' (Vizcaino, 2014). Nevertheless, one shariah compliant fund has been launched in Mauritius in 2010 by the Indian Multinational TATA Group named TATA Indian Shariah Equity Fund and till now is the only sukuk domiciled in the country (Parker, 2010).

\section{Bank Selection Criteria}

In conventional banking, a report by Ernst and Young (2010) reveals that price is the main element in Germany and Italian customers for their selection of bank. Caratelli and Ricci (2013) provides evidence from the U.S. that the most important factors for bank selection criteria are reputation and recommendation as compared to pricing. Results in South Africa show that the factors that customers go for are soundness and service with little regards to pricing (Coetzee, et.al.2012). In Pakistan, a study by Zulfiqar, et.al. (2014) shows that convenience, customer service and other facilities are more important for customers. In Indonesia the main factors in bank selection are customers' level of education, service quality and convenience (Abduh, et.al.2012). 
In Islamic banking, Hasan, et.al. (2012) and Ullah (2014) conduct a study in Pakistan. Their results show that religion comes second whereas the most important factor that customers look to choose their banks is service quality, high returns and low service charge. With regards to Bangladesh, Khan, et.al. (2008) investigates bank patronizing behavior and found that high income earners are more driven by religiosity to patronize Islamic banking whereas low income earners rely more on friends' recommendations. The study also confirms that profitability is not a significant factor in influencing bank selection criteria of individuals in Bangladesh.

Marimuthu, et.al. (2010) investigates the bank selection criteria for Islamic banking in Malaysia and discovers that the major factors to influence Islamic banking customers in Malaysia are the following, ranked 1 to 6 in order of respondents' preference; cost and benefits, convenience, service delivery, friend's influence, religion and size and reputation. It can be seen in the study that religion is not among the top three important factors. Similarly, Ranjbar and Sharif (2008) evidences that profitability is ranked first in Islamic banking selection criteria in Malaysia by the respondents and religion ranked second. Contrarily, Abduh, et.al. (2012) examines the same research and their results totally differed from the formers'. This study verifies that religion is the first factor to influence an individual's choice for Islamic banking followed by profitability and bank's reputation respectively.

Interestingly, literature available on Islamic banking patronizing behavior in Indonesia have shown that religion is a dynamic factor for it. Abduh and Omar (2010) shows that religion is the major factor which leads Indonesian to choose Islamic banks. The second factor which is also related to religion is the awareness of the fatwa issued by the National Ulema Council (MUI) on the similarity of conventional bank interest with ribaand followed by safety of funds and bank advertisement. The findings from Mariyono (2012) also confirm that religion comes first to high income Indonesian customers who patronize 
Islamic banking. However, low income earners prefer to go on the basis of recommendation. This study differs from others in the sense that it looks at the background of the respondents rather than their personal choices. For instance, according to his findings, entrepreneurs are more practical minded and are less likely to choose Islamic banking and finance. This suggests that several factors are behind Islamic banking patronizing behavior and this can range from personal choices such as service quality, profitability among others to the professional and family background of the customer.

In the case of the UK, Dar (2004) shows that UK Muslim population are more or less indifferent to shariah compliance. The study evidences that advertisement is one factor which leads UK Muslims towards Islamic banking. Another Muslim minority country where Islamic banking and finance has started to grow is Singapore. Similar to Dar (2004), Gerrard and Cunningham (1997) reports that both Muslims and Non-Muslims are not driven by religiosity but profit instead. However, their study lacked precision in the sense that the study was conducted back 1997 when Islamic banking was not implemented yet. This shows another drawback of the study since at that time both Muslims and Non-Muslims were unaware of the basic principles and mechanisms of Islamic banking as per their report.

With regard to Mauritius, being a Muslim minority country where Islamic banking and finance is particularly a new sphere, literature is still lacking in the area. However, Ramdhony (2013) investigates bank selection criteria in Mauritius and concludes that profitability and religion would go hand in hand among Muslims in the country for them to choose Islamic banking. Other two factors which play major role in influencing Mauritian Muslims' decision in patronizing Islamic banking are recommendations and the bank's advertisement.

This study is using the combination of factors influencing customers to patronize a bank from Abduh and Omar (2010), Ramdhony (2013) and Abduh (2017) in its questionnaire. The 
factors incorporated are return on savings or deposit, loan interest, service charges, service quality, transparency, privacy, bank reputation, easy access, friends/family recommendations, paperwork and documentation, variety of products, facilities offered, size of bank, and religion.

\section{Religiosity and Financial Activities}

The literature have shown that in many countries, even Muslim majority ones such as Pakistan, Bangladesh and Malaysia, religion or religiosity is not a dynamic element to draw customers towards Islamic finance. Similar to the way that conventional economics and finance are complementary to each other where one cannot exist without the other, Islamic finance is also founded upon the principles of Islamic economics. However, this does not mean people practicing the religion of Islam actually follow the principles of Islamic economics to guide their financial behavior. In fact, according to Islamic economics, a Muslim should be restricting themselves from spending too lavishly and be averse to speculative approaches whether in finance or in trade.

One study in Jordan by Ramadan (2013) establishes that religiosity is not a major factor in attracting Islamic banking customers. Similarly, Jalil and Rahman (2014) has found that Islamic norms do not influence customer choices much in Malaysia, however they also conclude that it is unseemly to generalize upon all banking consumers in the country based on their research. Furthermore, Tara, et.al. (2014) substantiate that religiosity chips in to around $15 \%$ in Islamic banking choices. On the other hand, Leon and Pfeifer (2013) finds that in general Muslims who tend to be more pious in Germany are less likely to invest in financial products which have prohibited elements such as gharar and riba present in them. In the same way, Alam, et.al. (2012) evidences that religiosity has a significant influence among Muslims in Malaysia who chose for Islamic home financing. Another study in Malaysia by Alam and Hisham (2011) also proven that religiosity is a major power towards Muslims consumer behavior. 
Therefore, it is to be noted that these literatures cannot prove whether religion matters or not on a general basis. It might all depend on the different culture of the people and the country and it might also depend on individual awareness, education and level of piousness. Hence, the alternative hypothesis $\left(\mathrm{H}_{\mathrm{a}}\right)$ with regard to the religiosity in this study is that religiosity has a significant influence on Islamic bank customers' patronizing behavior in Mauritius.

\section{Service Quality and Banking Industry}

Service quality is considered to be one of the most important aspects for any service industry's success. Zeithaml (1988) defines service quality as "an assessment of customer from the overall quality of service". According to Sachdev and Verma (2004) service quality is the most influential element in customer's buying decision. Therefore, they believe that the dynamic change in business environment today with improved and latest technologies, better regulatory settings among others have brought about a significant need for businesses to focus on the quality of their services.

Measuring the quality of services can be quite tricky compared to measuring the quality of a product. Parasuraman, et.al. (1988) state that "service quality is an abstract concept due to the intangibility, heterogeneity and inseparability of production and consumption". There are in fact, several models available to measure service quality in the research field. The most famous one though is the SERVQUAL model. The SERVQUAL was developed by Parasuraman, et.al. (1985) and further improved the model in 1988. The initial SERVQUAL model comprised of 10 dimensions which are tangibles, reliability, responsiveness, communication, credibility, security, competence, courtesy, understanding or knowing the customer and access and there were 97 items in all for the 10 dimensions. However, in their 1988 study they abridged these 10 dimensions into 5 since few of them were overlapping. 
The now used 5 dimensions of SERVQUAL are tangibles, reliability, assurance, responsiveness and empathy.

Many studies have been carried out to gauge the importance of service quality for banking customers. Auka, et.al. (2013) studies the effect of service quality dimensions on customer loyalty in Kenya. Their findings suggest that the quality of service delivered by a bank is directly related to customer loyalty. Similarly, Chaoprasert and Elsey (2004) investigates the implications of service quality improvement in the Thai banking sector and confirms that providing first class service quality would in fact retain customer loyalty. Many other studies such as Ladhari, et.al. (2011), Somasundaram and Krishnamurthy (2013) and Wafaa and Abderezzak (2014) have all emphasized on the importance of service quality and customer-bank relationship in the banking industry.

With regards to Islamic banking, service quality has been judged to be almost as important as compliance to shariah. A study in Malaysia by Shafie, et.al. (2004) has established that there is a strong significant relationship between customer satisfaction and service quality. However, they also confirm that the most important dimension among the customers is the shariah compliance dimension. It is to be noted that the standard SERVQUAL model comprises of 5 dimensions, however with regards to Islamic banking the $6^{\text {th }}$ dimension was added to the model namely the compliance to shariah one. Akhtar and Zaheer (2014) concludes the same thing from their study in the Gulf countries. Their findings suggest that tangibles have a big influence on customer satisfaction compared to other dimensions. Reliability is the next driving element for Islamic banking customers and Islamic banking products are reliable if they comply with the shariah.

On the other hand, it is quite interesting to note that in Iran the case is quite different. Iran is one of the two countries in the world which claims to have a $100 \%$ Islamic financial system. However, Amirzadeh and Shoorvarzy (2013) discovers that in Iran customers have placed more importance on "short and suitable 
queue", "confident and reliable staff" and "politeness of branch staff" compared to "being equal to Islamic doctrines" which is determined as being the least significant factor in service quality. However, they suggest that this may be due to the fact that since Iran has no conventional banks at all and it can be assumed that customers are assured of the fact that the banks in Iran comply perfectly with the rules of the shariah. Therefore, whether or not shariahcompliance is more important than other service quality factors depends on the different place and culture of the people.

Unlike the previous studies which analyze the performance of SERVQUAL dimensions, this study analyzes the level of both importance and performance of all the observed variables of the SERVQUAL dimensions individually using the importanceperformance analysis developed by Martilla and James (1977).

\section{Data and Method of Analysis}

\section{a. Data}

The data in this study are collected from Muslim banking customers in Mauritius using convenience sampling technique and the target of sample size to achieve is 384 respondents, as suggested by Krejcie and Morgan(1970). Nonetheless, only 136 questionnaires were able to be collected since some respondents were unwilling to respond and furthermore, some questionnaires proven to be invalid so they were discarded.

Data collection is using a set of questionnaire which is divided into three parts. The first part is demography where respondents' age, level of education, profession, income and other similar questions are included. The second part points out about the respondents' intention to patronize Islamic bank and analysis upon their selection criteria for banks. Lastly, the third part comprises of the SERVQUAL items to examine the bank's service quality and customer satisfaction level towards the Islamic bank's performances. 


\section{b. Reliability and Validity Test}

This study utilizes Cronbach's alpha and constructdiscriminant validity for the reliability and validity tests respectively. The value of the alpha ranges from zero to one but a value of 0.7 or above for alpha $(\alpha)$ is generally considered as being an acceptable measure of reliability. Meanwhile, the construct and discriminant validity would basically test whether those constructs that are supposed to be correlated are in fact so and one way to confirm this is through factor analysis.

\section{c. Factor Analysis}

Factor analysis is a data reduction method. In other words, it attempts to analyze whether a large number of variables is directly related to one single hidden or latent variable. In order to identify the underlying constructs or factors of a group of variables, EFA is carried out (Hair et al., 2011). This method only helps in finding out the dimensionality of a group of variables or simply helps a researcher to explore his variable. Subsequently, confirmatory factor analysis (CFA) is carried out. CFA is more in depth and more precise when it comes to validity check. Through CFA a researcher can thus define whether his model is proper or not and whether the constructs are as accurate as they are supposed to be. CFA is done in SPSS Amos which is a complementary software to SPSS. Factor analysis is also a dimension reduction procedure which helps in reducing the number of indicators per variable.

For this research factor analysis was carried on banking selection criteria and the SERVQUAL variable. When it comes to the former, theoretically they should all be related to selection criteria and also be highly correlated. EFA is run on SPSS and those variables with a factor loading of above 0.5 are deemed to be acceptable but above 0.7 are better. It is said that the nearer the loading is to 1 , the more accurate it is (Hair et al., 2011). That is, the higher the factor loading, the more it is able to explain the total variance. Further to this, while running EFA, the KMOBarlett's test of sphericity shows whether the sample size is 
satisfactory for running factor analysis. According to Beaumont (2012), the minimum value for the KMO above 0.5 and a p-value of lower than 0.001 indicates whether the researcher can proceed with the factor analysis.

The main reason behind running EFA before CFA is to explore the variable and detect any tricky item. According to Farell (2009), an item is said to be problematic for a construct when the item cross loads on more than one factor. This basically means that an item having a high loading value on more than 1 factor can cause validity problem. However, in order to be able to identify these items, a cut off threshold for cross loadings have to be set. There is a consensus among researchers that the cut off value can range from 0.3 to 0.5 (Farell, 2009) and the threshold set for this research is 0.4 . Items having obtained a factor loading of 0.4 and above on more than one factor were removed.

After taking all this into consideration, the researcher can thus go forward with the CFA and also see the model fit and perform convergent validity check. Accurate model fit basically indicates construct validity. There are few indices which indicates a model fit in Amos. These values are called Comparative Fit Index (CFI) and Tucker-Lewis Index (TLI) and both should ideally be above 0.9 but even a value of 0.8 might be considered acceptable since larger values indicate more accurate fit. Another index is the RMSEA which should be below 0.08 to denote a proper fit. Lastly, the normed chi-square value must range from 1-5 if the model is to be considered as a proper fit.

Following model fit, there are a series of measures which help in assessing convergent and divergent validity. Convergent validity is done by calculating the Average Variance Extracted (AVE) and the Composite Reliability (CR) value which should be above 0.5 and 0.7 respectively. The variable being tested for validity here is expected to have only one construct, which is bank selection criteria. Therefore, this research would perform only construct validity and discriminant validity test on the variable in 
question. After the variable being confirmed as both reliable and valid, inferential statistics will be performed.

\section{d. Importance - Performance Analysis}

Importance performance analysis is simply a marketing research tool designed to measure the importance of attributes and their performance (Abduh, 2011). It works in a way that the findings are plotted in a four-quadrant grid and each grid depicts the importance and/or performance of the items. The four quadrants are labelled as 'concentrate here', 'keep up the good work', 'low priority' and 'possible overkill'. This helps a researcher or a business in identifying which factors needs to be worked on or even possibly discard off and which factors are best for attracting customers.

Importance-performance analysis was developed by Martilla and James (1977) and according to them the placement of the lines which will constitute the quadrant is based upon judgement. The Importance-performance grid consists of two axes where the $\mathrm{x}$-axis shows performance and the $\mathrm{y}$-axis shows importance. The lines which will constitute the quadrant can be obtained by taking the grand-average of the importance and performance value collected from the respondents. In the case of this study, the SERVQUAL items will be plotted on an importanceperformance grid. Subsequently, it will help in identifying the primary service quality factors which Islamic banks can use to attract Muslim customers in Mauritius.

\section{Findings}

\section{a. Descriptive Statistic}

The demographic profile of the respondents comprises of gender, age group, level of education, occupation and income level. The information is demonstrated in Table 1 . It can be seen that there are more females than males. With regard to the age group, the majority of the respondents were below 30 years of age. Only $2.2 \%$ of the respondents were above 55 years of age.On the other hand, when it comes to education, the bulk of the respondents, 
more precisely 103 respondents or equivalent to $75.7 \%$, held a bachelor's degree or higher followed by $14.7 \%$ with education only till secondary level and $9.6 \%$ with professional qualification. This shows that the respondents are educated people and thus, the responses recorded is expected to reflect the real condition of Islamic banking customers in Mauritius.

In terms of occupation, as many as $37.8 \%$ of the respondents are found to be on a clerical positions followed by those in managerial positions with $28.1 \%$.Students involved in this study are constitute $22.2 \%$ of the total respondents and only $5.1 \%$ are in executive posts and $6.6 \%$ are unemployed. Therefore, it is believed that the respondents' involvement with banking activities is considered good.

With regards to income level, this question was put as optional since when it comes to revealing their monthly income level, many people are somehow reluctant. In all only $82.4 \%$ of the respondents actually responded to that question. Most of them (33.8\%) fill in the category of below 20 thousands Mauritian Rupees (MUR) or around USD600. Subsequently, as many as $27.2 \%$ respondents have earned between MUR20,000 MUR30,000 or around USD600 - USD900 and followed by 1.5\% respondents with an earning of above MUR40,000 or equivalent to USD1200.

Table 1. Demography of the Respondents

\begin{tabular}{|c|c|c|}
\hline & Frequency & Percentage \\
\hline \multicolumn{3}{|l|}{ Gender } \\
\hline Male & 57 & 41.9 \\
\hline Female & 79 & 58.1 \\
\hline \multicolumn{3}{|l|}{ Age Group } \\
\hline $18-30$ & 93 & 68.4 \\
\hline $31-45$ & 25 & 18.4 \\
\hline $46-55$ & 15 & 11 \\
\hline 55 and above & 3 & 2.2 \\
\hline \multicolumn{3}{|l|}{ Level of Education } \\
\hline Secondary & 20 & 14.7 \\
\hline Bachelors/Diploma & 86 & 63.2 \\
\hline Professional & 13 & 9.6 \\
\hline
\end{tabular}




\begin{tabular}{|l|c|c|}
\hline Masters/Ph.D. & 17 & 12.5 \\
\hline Occupation & 30 & 22.1 \\
\hline Student & 51 & 37.5 \\
\hline Clerical & 38 & 27.9 \\
\hline Managerial & 8 & 5.8 \\
\hline Executive & 9 & 6.6 \\
\hline Unemployed & \multicolumn{1}{|l|}{} \\
\hline Level of Income & 36 & 33.8 \\
\hline Below Rs 20 000 Below USD600 & 37 & 27.2 \\
\hline $\begin{array}{l}\text { Rs 20 000-30 000 } \approx \text { USD600 - } \\
\text { USD900 }\end{array}$ & 2 & 1.5 \\
\hline $\begin{array}{l}\text { Rs 30 000-40 000 } \\
\text { USD1200 USD900 - }\end{array}$ & 27 \\
\hline $\begin{array}{l}\text { Rs } 40000 \text { and above } \\
\text { above USD1200 and }\end{array}$ & & 19.9 \\
\hline
\end{tabular}

Further to this, the respondents were asked to provide their reasons for which they use a bank. This question was asked in order to understand the demand for banking in Mauritius and the answers include 'savings', 'loans', 'overdraft', 'business transactions' and 'others'. The following Table 2 shows the result obtained. It is interesting to note that $87.5 \%$ of the respondents said that the main purpose for their use of bank is for savings and the rest $12.5 \%$ chose for business transactions, however none of the respondent chose either for loan purpose or for overdraft purposes. This might imply that banking is considered only as the safest place to save the money for Muslims in Mauritius and therefore, improving the quality of services by the frontlines maybe the best approach to gain more trust and deposits.

Table 2. Purpose for Using a Bank

\begin{tabular}{|l|c|c|}
\hline & Frequency & Percentage \\
\hline Savings & 119 & 87.5 \\
\hline Business Transactions & 17 & 12.5 \\
\hline Total & 136 & 100 \\
\hline
\end{tabular}

In terms of religiosity, the question is set so the respondents will identify themselves as 'very religious', 'moderately religious' or 'indifferent'. The objective is to use the respondents' selfawareness about their religiosity and relate them with their attitude and patronizing behavior towards Islamic banking. 
The results are depicted in Table 3 and as expected, most of the respondents fell in the category of being moderately religious with $66.9 \%$ of them; $26.5 \%$ were found to be very religious and $6.6 \%$ being indifferent.

Table 3. Religiosity level of respondents

\begin{tabular}{|l|c|c|}
\hline & Frequency & Percentage \\
\hline Very religious & 36 & 26.5 \\
\hline Moderately religious & 91 & 66.9 \\
\hline Indifferent & 9 & 6.6 \\
\hline Total & 136 & 100 \\
\hline
\end{tabular}

With regard to the intention of using Islamic banking, the result to this question has shown that $82 \%$ of the respondents strongly agree to utilize Islamic banking, $10.6 \%$ of them select to disagree and $8 \%$ of them are neutral. Further analysis is provided in Table 4 which displays the cross-tabulationbetween the religiosity level of the respondents and the intention to use Islamic banking. The chi-squared independent test shows that p-value of 0.67 which is significantly higher than alpha 0.05 and thus it concludes that there is not enough evidence to support the alternative hypothesis proposed in this study which saying that religiosity as one of the driving factors of the bank patronizing behavior among the Mauritian Muslims.

Table 4. Crosstab of Religiosity and Intention to use Islamic Bank

\begin{tabular}{|l|c|c|c|}
\hline \multirow{2}{*}{ Religiosity } & \multicolumn{3}{|c|}{ Intention to Use Islamic Bank } \\
\cline { 2 - 4 } & Strongly Agree & Neutral & Disagree \\
\hline Very religious & 30 & 3 & 3 \\
\hline Moderately religious & 74 & 7 & 10 \\
\hline Indifferent & 8 & - & 1 \\
\hline Total (\%) & $112(82 \%)$ & $10(7.4 \%)$ & $14(10.6 \%)$ \\
\hline
\end{tabular}

The bank selection criteria question consisted of 15 likert scale items in all. Interestingly, only 6 items have been mostly chosen by the respondents as being highly likely to influence their choice of bank and these items are listed in Table 5. Based on those figures, it can be seen that the most common criteria which would highly likely to influence the bank selection of Muslims in Mauritius is privacy followed by easy access and service quality. 
Table 5. Bank selection criteria

\begin{tabular}{|l|c|c|}
\hline & Frequency & Percentage \\
\hline Privacy & 92 & 67.6 \\
\hline Easy access & 87 & 64 \\
\hline Service quality & 86 & 63.2 \\
\hline Transparency & 79 & 58.1 \\
\hline $\begin{array}{l}\text { Facilities offered } \\
\text { (payment of bills/mobile and internet banking etc) }\end{array}$ & 79 & 58.1 \\
\hline Bank reputation & 72 & 52.9 \\
\hline
\end{tabular}

The next criteria are transparency, facilities offered and bank reputation. Surprisingly, the religion factor received only $30.9 \%$ vote of being highly likely to be a selection criteria with $14 \%$ of respondent saying it might somewhat influence them and $39 \%$ were neutral. However, it also comes as a surprising factor that interest on savings also did not receive many votes with only $24.3 \%$ saying it would be highly likely to influence their decision in choosing a bank; $19.9 \%$ said they were somewhat influenced by interest on savings and $21.3 \%$ were neutral. Nevertheless, $32.4 \%$ of respondents said that interest would not influence their choice of bank at all.These figures suggest that most of the Mauritian Muslims are quite indifferent towards both interest income and religion.

\section{b. Reliability Test}

Cronbach alpha was computed for the whole questionnaire as well as different variables in the questionnaire. The result of Cronbach alpha for the whole questionnaire is 0.908 and for different variables in the questionnaire is as shown in Table 6.

Table 6. Reliability analysis for different variables

\begin{tabular}{|l|c|c|}
\hline \multicolumn{1}{|c|}{ Variable } & Cronbach Alpha & Number of Items \\
\hline Bank selection criteria & .799 & 15 \\
\hline SERVQUAL perception items & .939 & 16 \\
\hline SERVQUAL satisfaction items & .831 & 16 \\
\hline
\end{tabular}

These results show that all three variables and even the whole questionnaire have proven to be reliable since they surpass the required alpha value which is 0.7 or above according to Hair et al. (2011). This means that both the questionnaire and the variables give a good level of consistency in their results. However, 
as explained previously that a high reliability does not necessarily mean a good accuracy of the result. In order to test for validity, a factor analysis has to be carried out.

\section{c. Factor Analysis}

The results for factor analysis are presented in Table 7. The statistics for KMO and Barlett's test of sphericity show that the sample was just above the minimum requirement, however, since the p-value was below 0.001 it is considered reasonable to proceed with the factor analysis. Cross loading occurs when one item obtains relatively high factor loadings for more than one factor (Hair, et. al. 2011). Usually if an item has cross loading, it has to be dropped before carrying on to confirmatory factor analysis. However, the researcher should decide a proper threshold for the cross loading value.

Table 7. Sampling adequacy test for bank selection criteria

\begin{tabular}{|l|l|}
\hline KMO measure of sampling adequacy & .588 \\
\hline Barlett's test of sphericity - significance value & .000 \\
\hline
\end{tabular}

For this study, a cut off value of 0.4 is taken. After running the exploratory factor analysis, only 6 items are then chosen for the confirmatory factor analysis i.e. service quality, transparency, privacy, easy access, facilities offered and bank reputation.

Table 8. Confirmatory factor analysis for bank selection criteria

\begin{tabular}{|l|c|}
\hline Criteria & Factor Loading \\
\hline Service quality & .73 \\
\hline Transparency & .71 \\
\hline Privacy & .82 \\
\hline Easy access & .75 \\
\hline $\begin{array}{l}\text { Facilities offered } \\
\text { (Payment of bills, mobile/internet banking etc) }\end{array}$ & .76 \\
\hline Bank reputation & .77 \\
\hline
\end{tabular}

When it comes to assessing the validity of a certain variable, there are three criteria that have to be taken into consideration. First of all, only items with factor loadings of greater than 0.7 should be taken into account. Secondly, the AVE should be greater than 0.5 and lastly the CR should be above 0.7 . If these three conditions are met, it is said that the variable in question has 
convergent validity. The AVE and CR were computed for these items and the results are shown in the Table 9.The conclusion is that the bank selection criteria used in this study has achieved convergent validity

Table 9. Validity check for Bank Selection Criteria

\begin{tabular}{|l|c|c|}
\hline & AVE & CR \\
\hline Required value & $>0.5$ & $>0.7$ \\
\hline Actual value & 0.575 & 0.868 \\
\hline
\end{tabular}

\section{d. Importance - Performance Analysis}

After service quality is proven as an important bank selection criteria in Mauritius, importance-performance analysis will be used to identify which service quality items Islamic banks should focus more in order to be able to maintain existing customers and at the same time to attract new customers. In order to identify those items, the mean for importance and performance categories of every SERVQUAL items are computed and the results are presented in Table 10.

Table 10. Mean of SERVQUAL Items

\begin{tabular}{|c|c|c|c|c|}
\hline & & & Importance & Performance \\
\hline Dimension & & Item & Mean & Mean \\
\hline \multirow[t]{4}{*}{ Tangibles } & 1 & $\begin{array}{l}\text { The bank has up-to-date } \\
\text { and easily accessible } \\
\text { equipment }\end{array}$ & 4.32 & 3.85 \\
\hline & 2 & $\begin{array}{l}\text { Bank's employees are } \\
\text { decent and well-dressed }\end{array}$ & 3.87 & 3.32 \\
\hline & 3 & $\begin{array}{l}\text { The physical features } \\
\text { of the bank are visually } \\
\text { appealing }\end{array}$ & 3.71 & 4.03 \\
\hline & 4 & Easy access to the bank & 4.47 & 4.18 \\
\hline \multirow[t]{3}{*}{ Reliability } & 5 & $\begin{array}{l}\text { When the bank promises } \\
\text { to do something within } \\
\text { a certain time period, it } \\
\text { manages to do so. }\end{array}$ & 4.46 & 3.65 \\
\hline & 6 & $\begin{array}{l}\text { The bank keeps } \\
\text { proper record of your } \\
\text { transactions }\end{array}$ & 4.6 & 4 \\
\hline & 7 & $\begin{array}{l}\text { The bank's services are } \\
\text { error-free }\end{array}$ & 4.46 & 3.29 \\
\hline
\end{tabular}




\begin{tabular}{|c|c|c|c|c|}
\hline \multirow{3}{*}{$\begin{array}{l}\text { Respon- } \\
\text { siveness }\end{array}$} & 8 & $\begin{array}{l}\text { The bank has convenient } \\
\text { working hours }\end{array}$ & 4.6 & 3.82 \\
\hline & 9 & $\begin{array}{l}\text { Rapidity in service } \\
\text { delivery }\end{array}$ & 4.54 & 3.47 \\
\hline & 10 & $\begin{array}{l}\text { When you have a } \\
\text { problem, the bank has } \\
\text { your best interest at } \\
\text { heart in solving it }\end{array}$ & 4.55 & 3.18 \\
\hline \multirow[t]{3}{*}{ Assurance } & 11 & $\begin{array}{l}\text { Bank employees know } \\
\text { their job and provide } \\
\text { explicit explanation } \\
\text { regarding the products } \\
\text { and services }\end{array}$ & 4.57 & 3.47 \\
\hline & 12 & $\begin{array}{l}\text { There is transparency } \\
\text { and clarity regarding the } \\
\text { products, services and } \\
\text { fees }\end{array}$ & 4.54 & 3.15 \\
\hline & 13 & Confidentiality & 4.68 & 3.85 \\
\hline \multirow[t]{3}{*}{ Empathy } & 14 & $\begin{array}{l}\text { Employees are friendly } \\
\text { and well-mannered }\end{array}$ & 4.5 & 2.93 \\
\hline & 15 & $\begin{array}{l}\text { Bank employees provide } \\
\text { you with individual } \\
\text { attention }\end{array}$ & 4.54 & 2.5 \\
\hline & 16 & $\begin{array}{l}\text { Bank employees } \\
\text { understand your specific } \\
\text { needs }\end{array}$ & 4.45 & 2.46 \\
\hline
\end{tabular}

The items are numbered from 1 to 16 and in order to create the quadrant, the grand averages of importance and performance are computed from item 1 to item 16 . The results show that the grand average for importance and performance are 4.52 and 3.05 respectively. This implies that every service quality items with average importance less than 4.52 considered less important and every service quality items with average performance less than 3.05 are at risk of underperforming.

Figure 1 explains that seven items had already met the expectations of the respondents which are items number 6, 8, 9, $10,11,12$, and 13. Item 6 refers to "The bank keeps proper record of your transactions" which is part of Reliability dimension. Interestingly, items 8, 9, and 10 are all refer to Responsiveness dimension and items 11,12 , and 13 are all refer to Assurance dimension. This suggests that Islamic banks in Mauritius could emphasize their advertisement on the Responsiveness and 
Assurance dimensions instead of other factors which perceived less important or underperform.

Meanwhile, item 14 which refers to "Employees are friendly and well-mannered" and 16 which refers to "Bank employees understand your specific needs" are considered low in both importance and performance. Interestingly, item 15 which sourced from the same dimension of items 14 and 16 is also considered low in importance. This situation suggests that in general the respondents are not considering the dimension of Empathy as one of the important factors which the performance could drive them to patronize or to leave the bank. Despite its lower importance level set by the customers, item 15 has received performance value above the grand average which plots it at the "possible overkill" quadrant. In this sense the result of this study does not really tally with previous literature where Altwijry and Abduh (2013) found that the frontliner's friendliness was found to be of high importance and performance both in Saudi Arabia.

As can be seen in Figure 1, there are six items plotted in the "concentrate here" quadrant i.e. items number 1, 2, 3, 4, 5 and 7. Interestingly, items 1, 2, 3 and 4 are referred to Tangibles dimension and items 5 and 7 are referred to Reliability dimension. This suggests that Islamic banks in Mauritius must pay more attention to improve the Tangible and Reliability aspects in order to gain more trust from its existing and potential customers and eventually to gain more profit.

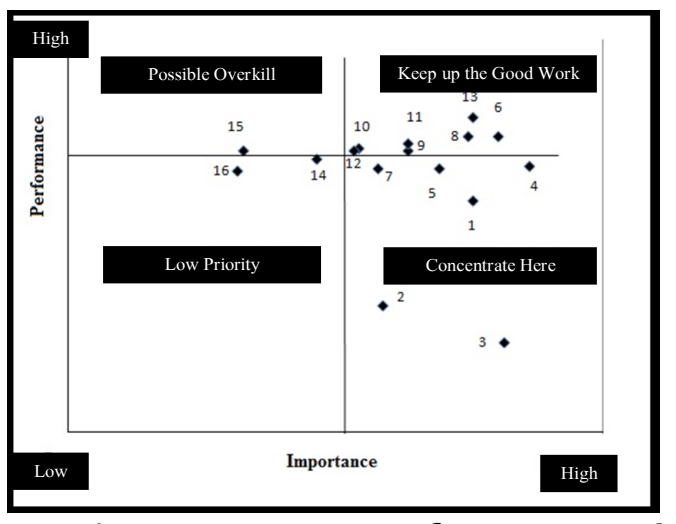

Figure 1. Importance-performance grid 


\section{Conclusion}

This study is aimed at investigating the bank selection criteria and Islamic bank SERVQUAL evaluation among Muslims in Mauritius. Interestingly, instead of religiosity, factors significantly influence Muslim in Mauritius in selecting bank are privacy, easy access, service quality, transparency, facilities offered and bank reputation. This implies that Islamic banks in Mauritius are facing rational type of customers and therefore, one of the best way to obtain more trust and eventually profit for the banks is by improving their quality of services. The importance - performance analysis is used in this study to evaluate the customers' perception upon the quality of services offered by Islamic banks in Mauritius. The finding indicates that in order to make Islamic bank more profitable, they are expected to improve the Tangible and Reliability aspects of service quality offered to their customers.

It is hoped that this study will provide better grounds for further study in the country on Islamic finance. This research only encompasses the field of Islamic banking, however, Islamic finance includes not only banks but also the capital and money markets and the Takaful industry. It is reasonable to anticipate that other study would explore those areas in Mauritius and probably contribute to the Islamic finance industry as a whole. Another point is that all of the literature available speaks from the perspective of consumers including this one. Nevertheless, literature is also required from the practical side and only then the industry players can properly understand the lack within this industry in Mauritius. 


\section{REFERENCES}

Abduh, M. (2011). Islamic Banking Service Quality and Withdrawal Risk: The Indonesian Experience. International Journal of Excellence in Islamic Banking and Finance, Vol. 1, No. 2, pp. $1-15$.

Abduh, M. (2017). Factors Influencing Russians to Patronize Islamic Financial Products and Services: Case Study in Dagestan and Tatarstan. Journal of Islamic Economics, Banking and Finance. Vol. 13 No. 3, pp. 163-173.

Abduh, M. and Omar, M. A. (2010). Who Patronizes Islamic Banks in Indonesia. Australian Journal of Islamic Law, Management and Finance. Vol. 1 No. 1, pp.40-53.

Abduh, M., Dahari, Z. and Omar, M. A. (2012). Bank Customer Classification in Indonesia: Logistic Regression vis-a-vis Artificial Neural Networks. World Applied Sciences Journal. Vol. 18 No. 7, pp.933-938.

Akhtar, A. and Zaheer, A. (2014). Service Quality Dimensions of Islamic Banks: A Scale Development Approach. Global Journal of Management and Business Research: A Administration and Management. Vol. 14 No. 5, pp.10-20.

Alam, S. S. and Hisham, R. (2011). Is Religiosity an Important Determinant on Muslim Consumer Behaviour in Malaysia. Journal of Islamic Marketing. Vol. 2 No. 1, pp.83-96.

Alam, S. S., Janor, H., Zanariah, Wel, C. A. and Ahsan, M. N. (2012). Is Religiosity an Important Factor in Influencing the Intention to Undertake Islamic Home Financing in Klang Valley. World Applied Sciences Journal. Vol. 19 No. 7, pp.1030-1041.

Altwijry, O. I. and Abduh, M. (2013). Customer Satisfaction and Switching Behaviour in Saudi Islamic Banks: An exploratory study. Journal of Islamic Finance. Vol. 2 No. 2, pp.17-25. 
Amirzadeh, R. and Shoorvarzy, M. R. (2013). Prioritizing Service Quality Factor in Iranian Islamic Banking using a Fuzzy Approach. International Journal of Islamic and Middle Eastern Finance and Management. Vol. 6 No. 1, pp.64-78.

Auka, D., Bosire, J. and Matern, V. (2013). Perceived Service Quality and Customer Loyalty in Retail Banking in Kenya. British Journal of Marketing Studies. Vol. 1 No. 3, pp.32-61.

Beaumont, R. (2012). An introduction to principal component analysis and factor analysis using SPSS 19 and $R$ (Psych Package). Retrieved from floppybunny.org: http://www. floppybunny.org/robin/web/virtualclassroom/stats / statistics2/pca1.pdf

Caratelli, M., and Ricci, O. (2013). Consumer Choice Criteria in Retail Banking. Journal of Strategic Choice Marketing. Vol. 22 No. 3, pp.240-256.

Century Banking Corporation Ltd. (2013). 2012 Annual Report of the Century Banking Corporation Ltd. Port Louis: Mauritius.

Chaoprasert, C. and Elsey, B. (2004). Service Quality Improvement in Thai Retail Banking and Its Management Implications. ABAC Journal. Vol. 4 No. 1, pp.47-66.

Coetzee, J., Zyl, H. V., and Tait, M. (2012). Selection criteria in the South African retail banking sector. African Journal of Business Management. Vol. 6 No. 41, pp.10558-10567.

Dar, H. (2004). Demand for Islamic financial services in the UK: Chasing a mirage? Economics Research Paper. Vol. 4 No. 11, pp.1-25.

Ernst and Young. (2010). Understanding Customer Behaviour in Retail Banking. London: Ernst and Young.

Farell, A. (2009). Factor analysis and discriminant validity:A brief review of some practical issues. Sydney: Australian and New Zealand Marketing Academy. 
Faye, I., Triki, T., and Kangoye, T. (2013). The Islamic Finance Promises: Evidence from Africa. Review of Development Finance, Vol. 3 No. 3, pp.136-151.

Gerrard, P. and Cunningham, J. B. (1997). Islamic banking:a study in Singapore. International Journal of Bank Marketing. Vol. 16 No. 6, pp.204-216.

Gunputh, R. P. (2012, October). Would Islamic Banking Enhance Banking Activities and FDI in Mauritius? The Mauritian Case Study. Paper presented at 2nd International Conference on International Trade and Investment'Financial Crisis and Trade and Investment in Developing Countries', Port Louis, Mauritius.

Hair, J. F., Celsi, M. W., Money, A. H., Samouel, P. and Page, M. J. (2011). Essentials of Business Research Methods. New York: M.E. Sharpe Inc.

Hasan, S. A., Subhani, M. I. and Osman, A. (2012). Consumer criteria for the selection of an Islamic bank:evidence from Pakistan. Retrieved from Munich Personal RePec Archive: http:// mpra.ub.uni-muenchen.de/40384/1/MPRA_paper_40384. pdf

Jalil, M. A. and Rahman, M. K. (2014). The Impact of Islamic Branding on Consumer Preference towards Islamic Banking Services: An Empirical Investigation in Malaysia. Journal of Islamic banking and finance. Vol. 2 No. 1, pp.209-229.

Jenkins, P. and Hall, C. (2012, October 5). HSBC's Islamic closures highlight dilemma. Retrieved from:http://www.ft.com/ intl/cms/s/0/bdb5f212-0f1c-11e2-9343-00144feabdc0. html\#axzz-31ycK0010

Khan, M. S., Hassan, M. K. and Shahid, A. I. (2008). Banking Behaviour of Islamic Bank Customers in Bangladesh. Journal of Islamic Economics, Banking and Finance. Vol. 3 No. 2, pp.159-194 
Krejcie, R. and Morgan, D. (1970, December). Determing sample size for research activities. The NEA Research Bulletin, 38, 99.

Ladhari, R., Souiden, N. and Ladhari, I. (2011). Determinants of loyalty and recommendation:the role of perceived service quality, emotional satisfaction and image. Journal of Financial Services Marketing. Vol. 16 No. 2, pp.111-124.

Lallmahamood, M. (2013, February 26). Mauritius: Why is Islamic finance not developing faster? Islamic Finance News Guide, p. 35. Retrieved from Islamic Finance News: http:// islamicfinancenews.com/contents/supplements/2013/ guide/guide.pdf

Leon, A. and Pfeifer, C. (2013). Religious activity, risk taking preferences, and financial behaviour:empirical evidence from German Survey Data. Working Paper Series in Economics. University of Luneberg.

Marimuthu, M., Jing, C. W., Gai, L. P., Mun, L. P. and Ping, T. Y. (2010, September). Islamic banking:selection criteria and implications. Global Journal of Human Sciences. Vol. 10 No. 4, pp.52-62.

Mariyono, J. (2012). Determinants of Customers in Selecting Sharia Banking System for Saving in East Java - Indonesia. Journal of Economics, Business and Accountancy Ventura. Vol. 16 No. 3, pp.457-472

Martilla, J. A., \& James, J. C. (1977). Importance performance analysis. The Journal of Marketing. Vol. 41 No. 1, pp.77-79.

Parasuraman, A., Zeithaml, V. and Berry, L. (1988). SERVQUAL: A Multiple Item-scale for Measuring Consumer Perceptions of Service Quality. Journal of Retailing. Vol. 64 No. 1, pp.1240. 
Parker, M. (2010, November 14). Indian Corporates TATA, Reliance foray into Islamic Finance. Retrieved from: http://arabnews. com/economy/islamicfinance/article190863.ece

Ramadan, Z. S. (2013). Jordanian Criteria for Islamic Banks Selection: Evidence from the Jordanian Banking Sector. International Journal of Academic Research in Accounting, Finance and Management Sciences. Vol. 3 No. 3, pp.139145.

Ramdhony, D. (2013). Islamic banking awareness attitudes and bank selection criteria. Internation Journal of Humanities and Applied Sciences. Vol. 2 No. 2, pp.29-35.

Ranjbar, A. and Sharif, S. P. (2008). Islamic banking selection criteria:an imperical study in Malaysia. Retrieved from Social Science Research Network: http://dx.doi.org/10.2139/ ssrn.1898663

Sachdev, S. and Verma, H. (2004). Relative Importance of Service Quality Dimensions:a multisectoral study. Journal of Services Research. Vol. 4 No. 1, pp.93-116.

Shafie, S., Azmi, W. N. and Haron, P. S. (2004). Adopting and Measuring Customer Service Quality in Islamic Banks: A Case Study of Bank Islam Malaysia Berhad. Journal of Muamalat and Islamic Finance Research. Vol. 1 No. 1, pp.112.

Somasundaram, R. and Krishnamurthy, V. (2013). Impact of service quality on customer relationship management in the banking sector. International Monthly Refereed Journal of Research in Management and Technology. Vol. 2, pp.102110.

Tara, N., Irshad, M., Khan, M. R. and Yamin, M. (2014). Factors Influencing Adoption of Islamic Banking: A Study from Pakistan. Journal of Public Administration and Governance. Vol. 4 No. 3, pp.352-367. 
Ullah, K. Z. (2014). An Investigation of the Selection Criteria of Islamic Banking in Pakistan: Customers' Perspective. Research Journal of Management Sciences. Vol. 3 No. 6, pp.7-9.

Vizcaino, B. (2014, March 5). Mauritius c.bank slams "footdragging" on Islamic finance, other reforms. Retrieved from: http://www.reuters.com/article/2014/03/05/islamicfinance-mauritius-idUSL6N0M204320140305

Wafaa, H. and Abderrezzak, B. (2014). A study of the relationship between banking service quality and customer satisfaction in Algerian public banks. International Journal of Science and Research. Vol. 3 No. 1, pp.372-378.

Zeithaml, V. (1988). Consumer Perceptions of Price, Quality and Value: A Means End Model and Synthesis of Evidence. Journal of Marketing. Vol. 52, pp.2-22.

Zulfiqar, B., Arshad, H. M., Fareed, Z., Shahzad, F., and Hussain, S. (2014). Criteria of selecting bank in Pakistani banking sector:study of banking customers in Sahiwal Pakistan. International Journal of Managing Value and Supply Chains. Vol. 5 No. 4, pp.19-30. 
|Muhamad Abduh et,al 